\title{
Reply to the letter by Dr. Hejna
}

\author{
Lisa B. E. Shields • Meredith Burge • \\ John C. Hunsaker III
}

Published online: 11 November 2011

(C) Springer Science+Business Media, LLC 2011

We thank Dr. Hejna both for his generous comment on our recent case report, Sudden death due to polyarteritis nodosa [1] (PAN), and for his gentle historical "correction”, namely, that the genial Bohemian pathologist and Professor of Pathology at the University of Vienna, Karel Rokitanský (Carl Freiherr von Rokitansky), published in a disquisition on aneurysms, the first "macroscopic" description of necrotizing arteritis in 1852 [2]. History confirms a well-documented evolution eventuating in the current nosology and diagnostic criteria for PAN, which were midwifed by many nineteenth century continental giants of medical science and pathology [3]. Like Dr. Hejna, we value Professor Rokitansky as Primus inter pares in discovering PAN. Rokitansky described systemic aneurysms-save the brain and aorta-in a 23-year-old male, who also had renal infarcts and ulcers of the colon. As Dr. Hejna avers, Rokitansky undertook no histopathology of the lesions, but rightly deserved credit for recognizing the characteristics of PAN. Interestingly, in 1881 Hans Eppinger Sr. examined Rokitansky's patient's (index case) vascular aneurysms microscopically and diagnosed necrotizing arteritis [4]. As indicated in our paper, we

L. B. E. Shields

Norton Neuroscience Institute, Louisville, KY, USA

M. Burge · J. C. Hunsaker III ( $\square)$

Office of the Associate Chief Medical Examiner, 100 Sower Boulevard, Suite 202, Frankfort, KY 40601-8271, USA

e-mail: John.Hunsaker@ky.gov

M. Burge J. C. Hunsaker III

Department of Pathology and Laboratory Medicine, University of Kentucky College of Medicine, Lexington, KY, USA concur with Jennette and Falk that "[t]he classic pathological description of necrotizing arteritis was published by ... Kussmaul and ... Maier in 1866." [5, 6]. In the inaugural number of German Archives of Clinical Medicine, these physicians, respectively an internist and a pathologist, did "... recognize the constellation of findings as a new clinical entity": microscopical examination exhibited inflammation and necrosis of the nodules of the muscular arteries and prompted them to call the disease "periarteritis nodosa" [3]. At present, the presumptive diagnosis of PAN is confirmed by histopathology of involved tissue that reveals the nature of the vasculitis.

\section{References}

1. Shields LB, Burge M, Hunsaker JC 3rd. Sudden death due to polyarteritis nodosa. Forensic Sci Med Pathol. 2011. doi: 10.1007/s12024-011-9290-1.

2. Von Rokitansky K. Über einige der wichtigsten Krankheiten der Arterien. Denkschr Kais Akad der Wissensch. 1852;4:1.

3. Stone JH. Polyarteritis nodosa (Clinician's corner). JAMA. 2002; 288:1632-9.

4. Eppinger H. Pathogenesis (Histogenesis und Aetiologie) der Aneurysmen einschliesslich des Aneurysma equi verminosum. Pathologisch-anatomische Studien. Arch Klin Chir. 1887; 35(suppl):1-553.

5. Jennette JC, Falk RJ. Clinical and pathological classification of ANCA-associated vasculitis: what are the controversies? Clin Exp Immunol. 1995;101(suppl 1):18-22.

6. Kussmaul A, Maier R. Über eine bisher nicht beschriebene eigenthümliche Arterienerkrankung (Periarteriitis nodosa), die mit Morbus Brightii und rapid fortschreitender allgemeiner Muske1lähmung einhergeht. Dtsch Arch Klin Med. 1866;1:484-518. 